\title{
Challenges of the accession process to the European Union: study case on adoption of the acquis communautaire chapter on social policy and employment
}

\author{
Simona Maria Stănescu, \\ Research Institute for Quality of Life, Romanian Academy \\ simonastanescu2014@gmail.com
}

DOI:10.5901/mjss.2014.v5n22p209

\begin{abstract}
Improvement of the EU social protection coordination is supported by monitor of social performances of the member states alongside adjustment of the negotiation process with candidate countries. The paper is focus on the evolution of adopting the social policy and employment chapter of the acquis communautaire in the case of fifth and sixth EU enlargements waves. The stable elements of this negotiation chapter are overviewed as well as period of time needed, and transitory measures established for each of the Central and East European countries. Comparative analyse of sensitive aspects within preaccession and post-accession phases support further in-depth understanding of EU versus domestic priorities in the social field. The research hypothesis is that the standard bureaucracy of adopting the social acquis communautaire is a rather "top down" decisional process than a "bottom up" one. Legislative harmonization and strengthening the institutional framework in the field of social policy and employment could create unexpected and even opposite effects related to long term national capacity of newly member state to accomplish EU common goals. In terms of methodology, the paper is based on desk research of domestic and EU regulations related to negotiation of social policy and employment chapter, EU and national monitoring reports. Preliminary research outputs focus on the two steps fifth wave of the EU enlargement (2004 and 2007) emphasized differences among countries "ready" to adopt the social acquis (i.g. Estonia, Malta) and "less ready" ones (Bulgaria, Poland, Romania). In terms of adaptation capacity to new socio-economic challenges, chapter 13 "Social policy and employment" of the fifth wave of EU accession process acquis communautaire became chapter 19 as part of the sixth one. The paper contributes to a constructive assessment of development of the acquis communautaire as an exercise to improve the social coordination with (potential) candidate countries to EU.
\end{abstract}

Keywords: accession to the European Union, social policy, acquis communautaire, Central and East European countries

\section{Arguments for a closer look at development of new member states}

Primary community regulations with impact on national social policies are broadly represented by the Roma Treaty (1958), the Community Charter of the Fundamental Social Rights of Workers (1989), the Maastricht Treaty (1992), and the Amsterdam Treaty (1997). The initial cooperation between the six EU founder states 1 was based on economic and politic cooperation promoting competition and free movement of goods, capital and persons. Within that context, marginal and exclusively economic related attention was paid to social regulations among member states. In this respect, first social measures were adopted to support the movement of workers and their families including the provision of social security. "European social space" launched in 1984 by Jacques Delors, the president of the European Commission was not focus on common social policy objectives as expected but rather on the dialogue between employers and employees (Zamfir, 1997, p. 244). Later on, the "European Social Model" will reflect a more adequate policy approach of social vulnerabilities and will promote common welfare exercises among member states.

Strategic EU platforms towards achieving common socio-economic goals were also represented by the Lisbon Strategy (2000), and the Europe 2020 Strategy. Launched in March 2000, the 10 years Lisbon Strategy proposed an ambitious goal for EU member states: "to become the most dynamic and competitive knowledge-based economy in the world by 2010 capable of sustainable economic growth with more and better jobs and greater social cohesion and respect for the environment". Lisbon Strategy mid term assessment (2005) emphasized implementation difficulties due to various socio-

\footnotetext{
1 Belgium, France, Germany, Italy, Luxembourg and the Netherlands
} 
economic as well as procedural reasons among which the two steps fifth EU enlargement wave1 was mentioned alongside national economies differences or unclear share of responsibilities and tasks between European and national levels. Pursuit of established Lisbon Strategy's goals parallel with EU standard accession procedures happened in the context of difficulties in bringing back the idea of planning in Central and Eastern European post-communist countries. These came as arguments in accepting the idea of insufficient research focus on enlargement of Central and East European countries and needed further analysis in this direction (European Parliament, 2010, pp. 57-58). Outputs of public consultation for launching the successor Europe 2020 pointed out that "a successful EU 2020 strategy must be built on a good analysis of the constraints facing policy makers in the coming years, and on the correct identification of the challenges to be tackled" (Commission of the European Communities, 2009, p. 3). Comparative sociologic publications developed during last years include statistic analysis and partially supported by qualitative approach (interviews with key stakeholders). Still, the analysis are focus on a rather EU member states' perspective than member states to EU which incompletely reveal domestic debates and strategic decisions confronted when adopting the consequent acquis communautaire' harmonisations legislative or institutional procedures. Further research is to be further conducted in order to better understand the national strategic motivation as hints in strengthen the domestic capacity. With the support of open method of coordination, both social engagements as national harmonised changes adopted within EU accession periods by 2005, 2007 and 2013 newly entered countries and newly common social directions (increase of employment rate) are to be respected. From this perspective the current paper supports the process of assessing national capacity of new member states from fifth and sixth enlargement waves to face the challenges of accomplishing EU commonly established and agreed social goals.

Adoption of EU structural decisions in developing social common actions as well as allocation of EU supporting budget (i.g. European Structural Funds) depend on absorption capacity of all member states. Lessons learned from successes and failures in this respect take into account EU's capacity to adequately and efficiently answer challenges permanently posed by international trends such as globalisation process, demographic trends, national investments of international economic players, climate and environment changes, and, last but not least, migration of labour force.

Identified "collective action problem" as reason for Lisbon failure is paradoxically generated by the fact that "countries find it in their national interest not to pursue policies that would support he overall collective European good as long as everyone else played by the rules. But because the incentives are the same for all, none will make the efforts necessary for achieving the common interest" (Collignon, 2006, p. 8). Careful analysis of national role, contribution and achievement of each member state in building EU plans is to be taken into account in all strategic phases in adopting such EU strategic decisions: design, allocation of needed resources and implementation. On the other hand, equally important is that simplified procedures in terms of EU coordination versus empowerment of national strategies were required. The need to reduce the deficit between member states against the argument that the whole process "become too complicated and is poorly understood. It generated much paper, but little action" (Commission of the European Communities, 2005, p. 29).

In 2005, a revised version of Lisbon Strategy was launched focus on four priority areas: „research and innovation, investing in people/modernizing labour markets, unlocking business potential, particularly of SMEs, and energy/climate change" (European Commission, 2010a, p. 2, 3). The closing evaluation of Lisbon Strategy made in 2010 emphasized the general positive impact as a total of 18 new jobs were created in all member states. Still, assumed objectives were not completely reached. In terms of employment rate prospects for 2010, starting point $62 \%$ registered in 2000 developed in $66 \%$ in 2008 and $70 \%$ in 2010. Supportive integrated employment guidelines addressed by the Commission to member states included: full employment, inclusive labour market, and lifecycle approach to work (Commission of the European Communities, 2007, p. 6). Labour market related target of follow up Europe 2020 is focus on $20-64$ population and refers to "at least $75 \%$ including through the greater involvement of women, older workers and the better integration of migrants in the work force" (European Commission, 2010b, p. 8). Within this context, common efforts are to be done in order to adequately support the empowerment of national engagement capacity towards supporting structural reforms at both EU and domestic levels.

\section{Negotiation of acquis communautaire in the social field}

Within accession to EU process candidate countries work on adopting the minim standards included in negotiation chapters of the acquis communautaire. They are not compulsory but harmonisation is requested at both legal and institutional level.

\footnotetext{
1 Ten new member states joined EU in 2010: Cyprus, Czeck Republic, Estonia, Hungary, Latvia, Lithuania, Malta, Poland, Slovakia, Slovenia. Two member states joined EU in 2007: Bulgaria, and Romania.
} 
Supporting pre-accession and post-accession financial tools are available for applicant member states. Negotiation process between EU and candidate countries bring together different national experiences and design to common policy elements identified as played a key role in functioning of EU as a whole.

We comparatively analyze the 2007 changes of acquis communautaire. In terms of composition of the acquis communautaire, previously composed by 31 chapters, the version used within the fifth enlargement wave was composed by 35 negotiation chapters. We take a closer look at development between acquis communautaire for the fifth comparatively with the sixth enlargement waves. 21 negotiation chapters were kept; others were either reshaping (eight chapters) or newly introduced (six chapters). The content of one 2005 negotiation chapter was distributed among other chapters. We present bellow in details the situation for each negotiation chapter. For more details please see table 1 included in annexes.

21 identical negotiation chapters were registered: Free movement of goods, Free movement of capital, Company law, Competition policy, Fisheries, Transport policy, Taxation, Economic and monetary policy, Statistics, Social policy and employment, Energy, Science and research, Regional policy and coordination of structural instruments, Environment, Consumer and health protection, Customs union, External relations, Financial control, Financial and budgetary provisions, Institutions, and chapter Other issues.

In terms of slightly changes of negotiation chapters, Chapter 15 Industrial policy and Chapter 16 Small and medium-sized enterprises merged in Chapter 20 Enterprise and industrial policy. Chapter 2 Free movement of persons became in 2007 Chapter 2 Freedom of movement for workers. Previsions of Chapter 3 Freedom to provide services were transferred to Chapter 3 Right of establishment and freedom to provide services. Chapter 7 Agriculture transformed in 2007 Chapter 11 Agriculture and rural development. Chapter 18 Education and training became Chapter 26 Education and culture. Chapter 19 Telecommunications and information technologies became Chapter 21 Trans-European Networks. Chapter 24 Cooperation in the field of justice and home affairs became Chapter 24 Justice, freedom and security. Chapter 27 Common foreign and security policy became Chapter 31 Foreign, security and defence policy

Previsions included in 2005 Chapter 20 Culture and audio-visual policy of the fifth EU enlargement wave were not kept as a whole but they were distributed among other negotiation chapters. 2007 newly introduced negotiation chapters were: Chapter 5 Public procurement, Chapter 7 Intellectual property law, Chapter 9 Financial services, Chapter 10 Information society and media, Chapter 12 Food safety, veterinary and phytosanitary policy, and Chapter 23 Judiciary and fundamental rights (Stanescu, 2013, pp. 271-274).

In what regards the social policy and employment chapter of the acquis communautaire, during negotiation period with countries from the fifth enlargement wave, the number of the chapter was 13. and it changed in chapter 19 as new negotiation chapters were added. Complex negotiation chapter 13 "Social policy and employment" tackled issues such us: employment (health and safety at work, labour legislation, social dialog), gender equality, migration, and social protection. The themes approached by ex-chapter 13 present points of common interest for other negotiation chapters such as Chapter 2 Free movement of persons, Chapter 7 Agriculture, Chapter 8 Fisheries, Chapter 15 Industrial policy, Chapter 16 Small and medium-sized enterprises, Chapter 18 Education and training, and Chapter 23 Consumer and health protection.

Regulations included in social policy and employment chapter do not require either the adoption of a particular regulation at the national level either the implementation of a particular rule. This process could be rather interpreted as a general important obligation to coordinate policies building a homogeny social framework towards EU treaty principles and rules (European Commission, 2004, p. 46).

Key elements included in the 2005 social policy and employment chapters are: employment, gender equality, antidiscrimination measures, health and work safety, social protection, social dialogue, public health. Comparatively, the sixth wave chapter include regulations relative to labour law, health and safety at work, social dialogue, employment policy, European Social Fund, social inclusion, social protection, anti-discrimination, and equal opportunities (European Commission, 2006, pp. 2-8)

Taking into account the amount of time requested for negotiating previsions included in chapter 13 "Social policy and employment", four categories of Central and East European countries could be identified. Candidate countries most "ready" to join EU were Malta, Latvia, and Slovakia. The second category in terms or readiness includes: Bulgaria, Cyprus, Lithuania, and Romania. Countries of the third category were: Estonia, Hungary, and Slovenia. The forth category of countries which needed the longest period of time included Check Republic and Poland. Two years of negotiations were registered in their cases. The analyse uses one semester of the EU presidency as common measurement indicator respecting the standard national accession reports as shown in the graph bellow. 
Graph: Time allocation for adopting chapter 13 Employment and social policy by candidate countries from five enlargement wave

Sourse: Stanescu, 2013, p. 161

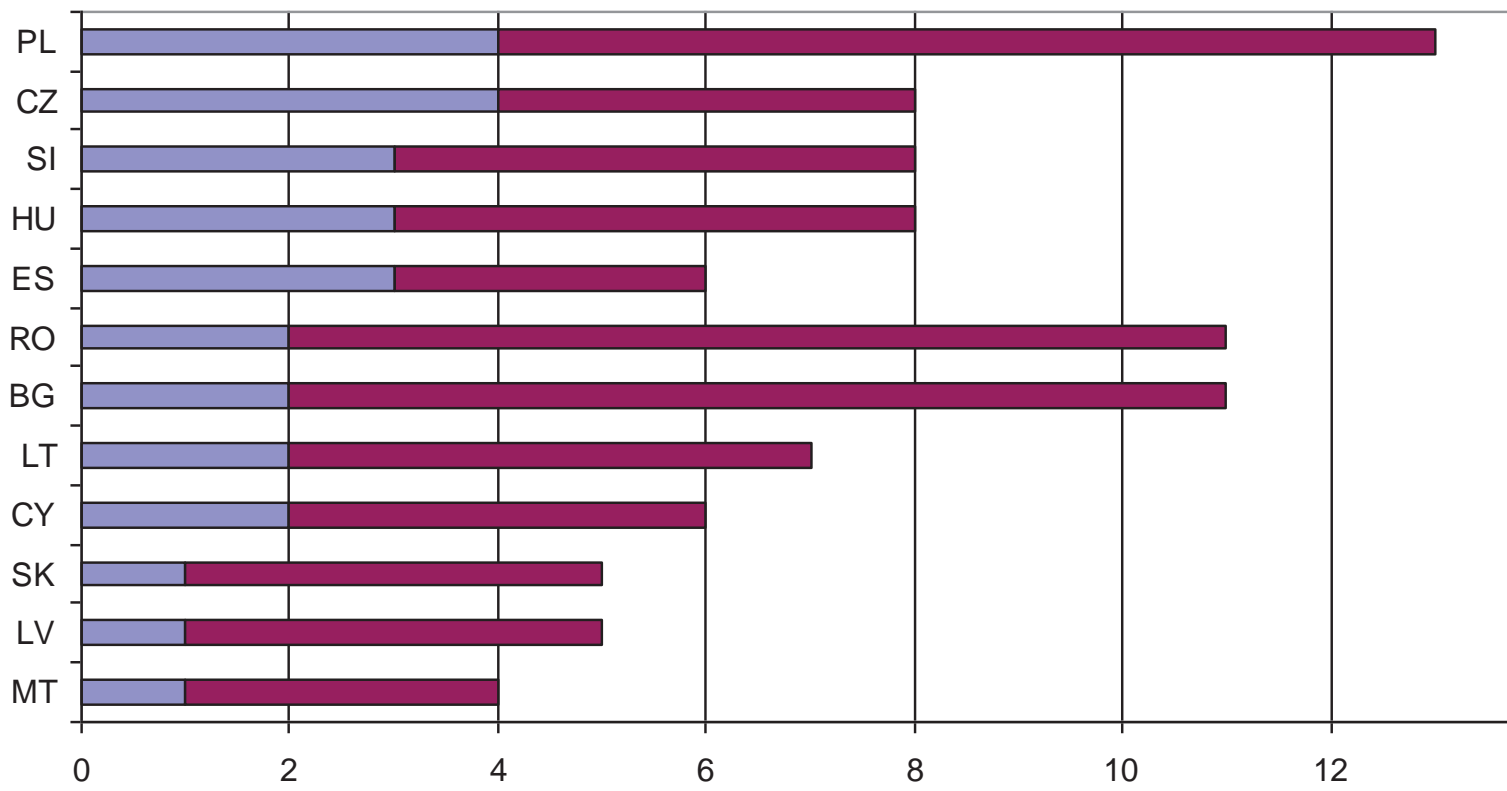

$\square$ Provisionally closed $\square$ Finally closed

Referring to the fifth EU enlargement wave, from the time perspective, negotiation of social policy and employment chapter was open in 1999, 2000, and 2001. September 1999 represented the beginning of harmonisation for six countries: Check Republic, Cyprus, Estonia, Hungary, Poland, and Slovenia. Latest openness of the chapter for negotiation was registered in the case of Lithuania and Malta: November 2001. Transitory measures were established for Bulgaria, Malta, Poland, and Slovenia. They included aspects related to: work equipment, workplace, working time, noise at work and so on. For more details please see table 2 included in the annexes.

\section{Conclusion and relevance}

The paper focused at the way negotiation process in the social field towards adopting chapter employment and social policy shape and challenge the national social policies. Accomplishment of both communities' regulations as well common social goals included within Lisbon Strategy and latest Europe 2020 Strategy impose a closer research of social transformation developed within latest member states especially due to harmonisation of acquis communautaire.

Results support a better understanding of five and six EU enlargement waves' countries capacity to face common responsibilities and achieve EU goals such as Europe Strategy 2020. Last but not least, research outputs contribute to a smooth harmonisation of social regulations for countries preparing to join EU: Albania, Bosnia and Herzegovina, the Former Yugoslav Republic of Macedonia, Iceland, Kosovo, Montenegro, Serbia, and Turkey.

\section{Acknowledgement}


This paper is made and published under the aegis of the Research Institute for Quality of Life, Romanian Academy as a part of a postdoctoral research programme co-funded by the European Union within the Operational Sectorial Programme for Human Resources Development through the project "Pluri and interdisciplinary in doctoral and post-doctoral programmes" Project Code: POSDRU/159/1.5/S/141086.

\section{References}

Collignon, S., 2006, Why Europe is not becoming the World's Most Dynamic Economy, The Lisbon Strategy, Macroeconomic Stability and the Dilemma of Governance with Governments, Pisa http://www.stefancollignon.de/PDF/NewLisbonStrategy_8nov.pdf

Stanescu, S. M., 2013. Statul bunăstării între supraviețuire, reformă și integrare europeană, București: Pro Universitaria Zamfir, C., 1997, Direcţii ale reformei statului bunăstării, în Zamfir, C.\& Zamfir, E. (eds.), Politici sociale în România în context european, Alternative Publishing House, Bucharest

Commission of the European Communities, 2007, Integrated Guidelines for Growth and Jobs (2008-2010) including a Commission recommendation on the broad guidelines for the economic policies of the Member States and the Community and a proposal for a Council Decision on guidelines for the employment policies of the Member States

Commission of the European Communities, 2005, Working together for growth and jobs A new start for the Lisbon Strategy, Communication from the Commission to the Spring European Council, Brussels

Commission of the European Communities, 2009, Consultation on the future "EU 2020" Strategy, Commission working document, Brussels

European Commission, 2004, Enlargement of the European Union -Guide to the Negotiations Chapter by Chapter, Directorate-General Enlargement, Information \& Interinstitutional Relations

http://europa.eu.int/comm/enlargement/negotiations/chapters/negotiationsguide.pdf

European Commission, 2006, Screening report Croatia, Chapter 19 - Social policy and employment

European Commission, 2010a, Lisbon Strategy evaluation document, Commission staff working document, Brussels

European Commission, 2010b, Europe 2020, A strategy for smart, sustainable and inclusive growth, Brussels

European Parliament, 2010, The Lisbon Strategy 2000-2010 An analysis and evaluation of the methods used and resutls achieved, Directorate General for Internal Policies, Policy Department Economic and Scientific Policy

http://www.europarl.europa.eu/document/activities/cont/201107/20110718ATT24270/20110718ATT24270EN.pdf

http://ec.europa.eu/enlargement/archives/enlargement_process/future_prospects/negotiations/eu10_bulgaria_romania/ch apters/chap_13_en.htm

\section{Annexes}

Table 1. Development by chapters of negotiations of the acquis communautaire used for fifth and sixth EU enlargement waves

Source: Stanescu, 2013, pp. 271-274

\begin{tabular}{|l|l|l|l|l|l|l|}
\hline \multirow{2}{*}{ No. } & \multicolumn{3}{|l|}{ Identical chapter } & \multicolumn{2}{l|}{ Modified chapter } & \multicolumn{2}{l|}{ New chapter } \\
\cline { 2 - 6 } & $\begin{array}{l}\text { 5th } \\
\text { enlargement }\end{array}$ & $\begin{array}{l}\text { 6th } \\
\text { enlargement }\end{array}$ & 5th enlargement & 6th enlargement & $\begin{array}{l}\text { 5th } \\
\text { enlargement }\end{array}$ & $\begin{array}{l}\text { 6th } \\
\text { enlargement }\end{array}$ \\
\hline & $\begin{array}{l}\text { Chapter 1 - Free movement } \\
\text { of goods }\end{array}$ & & $\begin{array}{l}\text { Chapter 2 - Free } \\
\text { movement of persons }\end{array}$ & $\begin{array}{l}\text { Freedom 2 of } \\
\text { movement for } \\
\text { workers }\end{array}$ & & \\
\hline & & & & \\
\hline
\end{tabular}




\begin{tabular}{|c|c|c|c|c|c|c|}
\hline \multirow[b]{2}{*}{ No. } & \multicolumn{2}{|c|}{ Identical chapter } & \multicolumn{2}{|l|}{ Modified chapter } & \multicolumn{2}{|l|}{ New chapter } \\
\hline & $\begin{array}{l}\text { 5th } \\
\text { enlargement }\end{array}$ & $\begin{array}{l}\text { 6th } \\
\text { enlargement }\end{array}$ & 5th enlargement & 6th enlargement & $\begin{array}{l}\text { 5th } \\
\text { enlargement }\end{array}$ & $\begin{array}{l}\text { 6th } \\
\text { enlargement }\end{array}$ \\
\hline & & & $\begin{array}{l}\text { Chapter } 3 \text { - Freedom } \\
\text { to provide services }\end{array}$ & $\begin{array}{l}\text { Chapter } 3- \\
\text { Right of } \\
\text { establishment } \\
\text { and freedom to } \\
\text { provide services }\end{array}$ & & \\
\hline & \multicolumn{2}{|c|}{$\begin{array}{l}\text { Chapter } 4 \\
\text { Free movement of capital }\end{array}$} & & & & \\
\hline & & & & & & $\begin{array}{l}\text { Chapter } 5 \text { - } \\
\text { Public } \\
\text { procurement }\end{array}$ \\
\hline & \multicolumn{2}{|c|}{$\begin{array}{l}\text { Chapter } 5(2004) / 6 \text { (2007) } \\
\text { Company law }\end{array}$} & & & & \\
\hline & & & & & & $\begin{array}{l}\text { Chapter } 7 \text { - } \\
\text { Intellectual } \\
\text { property law }\end{array}$ \\
\hline & \multicolumn{2}{|c|}{$\begin{array}{l}\text { Chapter } 6 \text { (2004)/ } 8 \text { (2007) } \\
\text { Competition policy }\end{array}$} & & & & \\
\hline & & & & & & $\begin{array}{ll}\text { Chapter } 9 \text { - } & \\
\text { Financial } & \\
\text { services } & \end{array}$ \\
\hline & & & & & & $\begin{array}{l}\text { Chapter } 10- \\
\text { Information } \\
\text { society and } \\
\text { media }\end{array}$ \\
\hline & & & $\begin{array}{llll}\text { Chapter } & 7 & - \\
\text { Agriculture } & & \end{array}$ & $\begin{array}{l}\text { Chapter } 11- \\
\text { Agriculture and } \\
\text { rural } \\
\text { development }\end{array}$ & & \\
\hline & & & & & & $\begin{array}{l}\text { Chapter } 12- \\
\text { Food safety, } \\
\text { veterinary and } \\
\text { phytosanitary } \\
\text { policy }\end{array}$ \\
\hline & \multicolumn{2}{|c|}{$\begin{array}{l}\text { Chapter } 8(2004) / 13(2007) \\
\text { Fisheries }\end{array}$} & & & & \\
\hline & \multicolumn{2}{|c|}{$\begin{array}{l}\text { Chapter } 9 \text { (2004)/ } 14 \text { (2007) } \\
\text { Transport policy }\end{array}$} & & & & \\
\hline & \multicolumn{2}{|c|}{$\begin{array}{l}\text { Chapter } 10(2004) / 16(2007) \\
\text { Taxation }\end{array}$} & & & & \\
\hline & \multicolumn{2}{|c|}{ Chapter 11 (2004)/ 17 (2007) } & & & & \\
\hline
\end{tabular}




\begin{tabular}{|c|c|c|c|c|c|c|}
\hline \multirow[b]{2}{*}{ No. } & \multicolumn{2}{|c|}{ Identical chapter } & \multicolumn{2}{|l|}{ Modified chapter } & \multicolumn{2}{|l|}{ New chapter } \\
\hline & $\begin{array}{l}\text { 5th } \\
\text { enlargement }\end{array}$ & $\begin{array}{l}\text { 6th } \\
\text { enlargement }\end{array}$ & 5th enlargement & 6th enlargement & $\begin{array}{l}\text { 5th } \\
\text { enlargement }\end{array}$ & $\begin{array}{l}\text { 6th } \\
\text { enlargement }\end{array}$ \\
\hline & \multicolumn{2}{|c|}{$\begin{array}{l}\text { Economic and monetary } \\
\text { policy }\end{array}$} & & & & \\
\hline & \multicolumn{2}{|c|}{$\begin{array}{l}\text { Chapter } 12(2004) / 18(2007) \\
\text { Statistics }\end{array}$} & & & & \\
\hline & \multirow{2}{*}{\multicolumn{2}{|c|}{$\begin{array}{l}\text { Chapter } 13(2004) / 19 \text { (2007) } \\
\text { Social policy and employment }\end{array}$}} & & & & \\
\hline & & & & & & \\
\hline & \multicolumn{2}{|c|}{$\begin{array}{l}\text { Chapter } 14(2004) / 15 \text { (2007) } \\
\text { Energy }\end{array}$} & & & & \\
\hline & & & $\begin{array}{l}\text { Chapter } 15 \text { - Industrial } \\
\text { policy }\end{array}$ & \multirow{2}{*}{$\begin{array}{l}\text { Chapter } 20- \\
\text { Enterprise and } \\
\text { industrial policy }\end{array}$} & & \\
\hline & & & $\begin{array}{l}\text { Chapter } 16 \text { - Small } \\
\text { and medium-sized } \\
\text { enterprises }\end{array}$ & & & \\
\hline & \multirow{2}{*}{\multicolumn{2}{|c|}{$\begin{array}{l}\text { Chapter } 17(2004) / 25(2007) \\
\text { Science and research }\end{array}$}} & & & & \\
\hline & & & & & & \\
\hline & & & $\begin{array}{l}\text { Chapter } 18 \quad- \\
\text { Education and training }\end{array}$ & $\begin{array}{l}\text { Chapter } 26- \\
\text { Education and } \\
\text { culture }\end{array}$ & & \\
\hline & & & $\begin{array}{l}\text { Chapter } 19 \text { - } \\
\text { Telecommunications } \\
\text { and information } \\
\text { technologies }\end{array}$ & $\begin{array}{l}\text { Chapter } 21 \text { - } \\
\text { Trans-European } \\
\text { Networks }\end{array}$ & & \\
\hline & & & & & $\begin{array}{l}\text { Chapter } 20 \text { - } \\
\text { Culture and } \\
\text { audio-visual } \\
\text { policy }\end{array}$ & \\
\hline & \multirow{2}{*}{\multicolumn{2}{|c|}{$\begin{array}{l}\text { Chapter } 21(2004) / 22 \text { (2007) } \\
\text { Regional policy and } \\
\text { coordination of structural } \\
\text { instruments }\end{array}$}} & & & & \\
\hline & & & & & & \\
\hline & & & & & & $\begin{array}{l}\text { Chapter } 23- \\
\text { Judiciary and } \\
\text { fundamental } \\
\text { rights }\end{array}$ \\
\hline & \multirow{2}{*}{\multicolumn{2}{|c|}{$\begin{array}{l}\text { Chapter } 22(2004) / 27 \text { (2007) } \\
\text { Environment }\end{array}$}} & & & & \\
\hline & & & & & & \\
\hline & \multicolumn{2}{|c|}{ Chapter 23 (2004)/ 28 (2007) } & & & & \\
\hline & $\begin{array}{l}\text { Consumer } \\
\text { protection }\end{array}$ & and health & & & & \\
\hline
\end{tabular}




\begin{tabular}{|c|c|c|c|c|c|c|}
\hline \multirow[b]{2}{*}{ No. } & \multicolumn{2}{|c|}{ Identical chapter } & \multicolumn{2}{|l|}{ Modified chapter } & \multicolumn{2}{|l|}{ New chapter } \\
\hline & $\begin{array}{l}\text { 5th } \\
\text { enlargement }\end{array}$ & $\begin{array}{l}\text { 6th } \\
\text { enlargement }\end{array}$ & 5th enlargement & 6th enlargement & $\begin{array}{l}\text { 5th } \\
\text { enlargement }\end{array}$ & $\begin{array}{l}\text { 6th } \\
\text { enlargement }\end{array}$ \\
\hline & & & $\begin{array}{l}\text { Chapter } 24- \\
\text { Co-operation in the } \\
\text { field of justice and } \\
\text { home affairs }\end{array}$ & $\begin{array}{l}\text { Chapter } 24- \\
\text { Justice, freedom } \\
\text { and security }\end{array}$ & & \\
\hline & \multicolumn{2}{|c|}{$\begin{array}{l}\text { Chapter } 25(2004) / 29(2007) \\
\text { Customs union }\end{array}$} & & & & \\
\hline & \multicolumn{2}{|c|}{$\begin{array}{l}\text { Chapter } 26(2004) / 30(2007) \\
\text { External relations }\end{array}$} & & & & \\
\hline & & & $\begin{array}{l}\text { Chapter } 27 \text { - Common } \\
\text { foreign and security } \\
\text { policy }\end{array}$ & $\begin{array}{l}\text { Chapter } 31- \\
\text { Foreign, } \\
\text { security and } \\
\text { defence policy }\end{array}$ & & \\
\hline & \multicolumn{2}{|c|}{$\begin{array}{l}\text { Chapter } 28(2004) / 32(2007) \\
\text { Financial control }\end{array}$} & & & & \\
\hline & \multicolumn{2}{|c|}{$\begin{array}{l}\text { Chapter } 29(2004) / 33(2007) \\
\text { Financial and budgetary } \\
\text { provisions }\end{array}$} & & & & \\
\hline & \multicolumn{2}{|c|}{$\begin{array}{l}\text { Chapter } 30(2004) / 34(2007) \\
\text { Institutions }\end{array}$} & & & & \\
\hline & \multicolumn{2}{|c|}{$\begin{array}{l}\text { Chapter } 31(2004) / 35(2007) \\
\text { Other issues }\end{array}$} & & & & \\
\hline
\end{tabular}

Tabel 2. Negotiation of chapter 13 Social policy and employment by Central and East European countries of fifth enlargement

\begin{tabular}{|c|c|c|c|c|c|}
\hline No. & Country & Chapter open & $\begin{array}{l}\text { Provisionally } \\
\text { closed }\end{array}$ & Closed & Transitional arrangements \\
\hline & Bulgary & October 2001 & April 2002 & $\begin{array}{l}\text { December } \\
2004\end{array}$ & $\begin{array}{l}\text { maximum tar yield of cigarettes (till } 31 \\
\text { December 2010) }\end{array}$ \\
\hline & Cyprus & $\begin{array}{l}\text { September } \\
1999\end{array}$ & March 2000 & $\begin{array}{l}\text { December } \\
2002\end{array}$ & - \\
\hline & $\begin{array}{l}\text { Czeck } \\
\text { Republic }\end{array}$ & $\begin{array}{l}\text { September } \\
1999\end{array}$ & May 2001 & $\begin{array}{l}\text { December } \\
2002\end{array}$ & - \\
\hline & Estonia & $\begin{array}{l}\text { September } \\
1999\end{array}$ & October 2000 & $\begin{array}{l}\text { December } \\
2002\end{array}$ & - \\
\hline & Hungary & $\begin{array}{l}\text { September } \\
1999\end{array}$ & November 2000 & $\begin{array}{l}\text { December } \\
2002\end{array}$ & - \\
\hline & Latvia & $\begin{array}{l}\text { February } \\
2001\end{array}$ & June 2001 & $\begin{array}{l}\text { December } \\
2002\end{array}$ & $\begin{array}{l}\text { work equipment (til } 1 \text { July 2004) } \\
\text { workplace (til } 31 \text { December 2004) }\end{array}$ \\
\hline
\end{tabular}




\begin{tabular}{|l|l|l|l|l|l|}
\hline No. & Country & Chapter open & $\begin{array}{l}\text { Provisionally } \\
\text { closed }\end{array}$ & Closed & Transitional arrangements \\
\hline & & & & & $\begin{array}{l}\text { Display screen equipment (til } 31 \\
\text { December 2004) }\end{array}$ \\
\hline & Lithuania & $\begin{array}{l}\text { November } \\
2000\end{array}$ & March 2001 & $\begin{array}{l}\text { December } \\
2002\end{array}$ & - \\
\hline & Malta & $\begin{array}{l}\text { November } \\
2001\end{array}$ & November 2001 & $\begin{array}{l}\text { December } \\
2002\end{array}$ & $\begin{array}{l}\text { Working time (till 31 December 2004) } \\
\text { Work equipment (till 2005) }\end{array}$ \\
\hline & Poland & $\begin{array}{l}\text { September } \\
1999\end{array}$ & March 2001 & $\begin{array}{l}\text { December } \\
2002\end{array}$ & Work equipment (till 2005) \\
\hline & Romania & October 2001 & April 2002 & $\begin{array}{l}\text { December } \\
2004\end{array}$ & $\begin{array}{l}\text { December } \\
2002\end{array}$ \\
\hline & Slovakia & $\begin{array}{l}\text { February } \\
2001\end{array}$ & May 2001 & $\begin{array}{l}\text { December } \\
2002\end{array}$ & $\begin{array}{l}\text { Biological agents (till 2005) } \\
\text { Noise at work (till 2005) } \\
\text { Chemical, physical and biological } \\
\text { agents at work } \\
\text { (till 2005) }\end{array}$ \\
\hline
\end{tabular}

